\title{
Mortality of Plutella xylostella (Lepidoptera, Plutellidae) by parasitoids in the Province of Santa Fe, Argentina
}

\author{
Isabel Bertolaccini ${ }^{1}$, Daniel E. Sánchez ${ }^{1}$, María C. Arregui ${ }^{1}$, Juan C. Favaro ${ }^{1} \&$ Natalia Theiler $^{1}$
}

${ }^{1}$ Departamento de Producción Vegetal, Facultad de Ciencias Agrarias (U.N.L.), Kreder 2805, (3080) Esperanza (Santa Fe), Argentina. isabelb@fca.unl.edu.ar; nataliatheiler@hotmail.com; dsanchez@fca.unl.edu.ar; carregui@fca.unl.edu.ar; jcfavaro@fca.unl.edu.ar

\begin{abstract}
Mortality of Plutella xylostella (Lepidoptera, Plutellidae) by parasitoids in the Province of Santa Fe, Argentina. Plutella xylostella (Linnaeus, 1758) (Lepidoptera, Plutellidae) larvae cause severe economic damage on cabbage, Brassica oleracea L. variety capitata (Brassicaceae), in the horticultural fields in the Province of Santa Fe, Argentina. Overuse of broad spectrum insecticides affects the action of natural enemies of this insect on cabbage. The objectives of this work were to identify the parasitoids of $P$. xylostella and to determine their influence on larva and pupa mortality. Weekly collections of larvae and pupae were randomly conducted in cabbage crops during spring 2006 and 2007. The immature forms collected were classified according to their developmental stage: $\mathrm{L} 1$ and $\mathrm{L} 2$ ( $\mathrm{Ls}=$ small larvae), L3 ( $\mathrm{Lm}=$ medium larvae), $\mathrm{L} 4(\mathrm{Ll}=$ large larvae), pre-pupae and pupae $(\mathrm{P})$. Each individual was observed daily in the laboratory until the adult pest or parasitoid emergence. We identified parasitoids, the number of instar and the percentage of mortality of P. xylostella for each species of parasitoid. Parasitoids recorded were: Diadegma insulare (Cresson, 1875) (Hymenoptera, Ichneumonidae), Oomyzus sokolowskii (Kurdjumov, 1912) (Hymenoptera, Eulophidae), Cotesia plutellae (Kurdjumov, 1912) (Hymenoptera, Braconidae) and an unidentified species of Chalcididae (Hymenoptera). Besides parasitoids, an unidentified entomopathogenic fungus was also recorded in 2006 and 2007. In 2006, the most successful parasitoids were $D$. insulare and $O$. sokolowskii, while in 2007 only $D$. insulare exerted a satisfactory control and it attacked the early instars of the pest.
\end{abstract}

KEYWORDS. Brassica oleracea cv. capitata; Cotesia plutellae; Diadegma insulare; diamondback moth (DBM); Oomyzus sokolowskii.

RESUMO. Mortalidade de Plutella xylostella (Lepidoptera, Plutellidae) por parasitóides na Província de Santa Fé, Argentina. Plutella xylostella (Linnaeus, 1758) (Lepidoptera, Plutellidae) causa danos econômicos severos em repolho, Brassica oleracea variedade capitata L. (Brassicaceae), na área de horticultura localizada na Província de Santa Fé, Argentina. O uso excessivo de inseticidas de largo espectro afeta a ação dos inimigos naturais de $P$. xylostella em repolho. O presente trabalho teve como objetivo identificar os parasitóides de P. xylostella e determinar sua influência na mortalidade de larvas e pupas em Santa Fé, Argentina. Coletas semanais de larvas e pupas em culturas de repolho foram realizadas aleatoriamente na área durante a primavera de $2006 \mathrm{e}$ 2007, registradas pelo estágio de desenvolvimento: L1 e L2 (Ls = larvas pequenas), (Lm = larvas médias) L3, L4 (L1 = larvas grandes) pré-pupa e pupa (P). Cada indivíduo foi observado diariamente no laboratório até a emergência dos adultos da praga ou dos parasitóides. Foram identificadas as espécies de parasitóides o número de instars e a porcentagem de mortalidade. Os parasitóides registrados foram: Diadegma insulare (Cresson, 1875) (Hymenoptera, Ichneumonidae), Oomyzus sokolowskii (Kurdjumov, 1912) (Hymenoptera, Eulophidae), Cotesia plutellae (Kurdjumov, 1912) (Hymenoptera, Braconidae) e uma espécie não identificada pertencente à família Chalcididae. Além dos parasitóides, um fungo entomopatogênico não identificado foi registrado. Em 2006, os parasitóides mais bem sucedidos foram $D$. insulare e $O$. Sokolowskii; enquanto que em 2007 apenas $D$. insulare exerceu um controle satisfatório, atacando os instares iniciais da praga.

PALAVRAS-CHAVE. Brassica oleracea var. capitata; Cotesia plutellae; Diadegma insulare; Oomyzus sokolowskii; traça-das-crucíferas.

The Diamondback moth (DBM), Plutella xylostella (Linnaeus, 1758) (Lepidoptera, Plutellidae), is a cosmopolitan pest of wild and cultivated Brassicaceae plants (Mussury et al. 2002; Ulmer et al. 2002). It is adapted to different climatic conditions (Martínez-Castillo et al. 2002) and causes serious economic losses worldwide (Jankowska \& Wiech 2006).

DBM presents high genetic variability (Garcia Campos et al. 2006), large number of annual generations, and high fertility (Ulmer et al. 2002), which facilitate the development of resistance to insecticides. Cross-resistance for organophosphates and pyrethroids has been observed (Yun Cheng 1985). Sarfraz \& Keddie (2005) reported the physiological capacity of P. xylostella to detoxify glucosinolates, the natural defense system of Brassicaceae.

DBM integrated pest management combines adequate pesticide use, biological control, floristic diversity in the field and trapping crops. Biological control can be very effective if control agents are available. There are over 90 parasitoid species recorded attacking the DBM larvae and pupae in integrated pest management programs for commercial cabbage production (Jankowska \& Wiech 2006; Furlong et al. 2004). 
Parasitoids attack the pest in different developmental stages. It is relevant to determine the association between biological control agents and specific stages of the pests to improve biological control strategies.

Despite the importance of DBM in Argentina and the frequent insecticide applications for its control, few studies have been conducted to determine natural mortality factors. The aim of this study was to survey the parasitoid species attacking DBM in different developmental stages and to determine their mortality impact on DBM in cabbage.

Field samples were taken in a commercial farm located in the horticultural region of the Province of Santa Fe $\left(60^{\circ} 50^{\prime} \mathrm{W}, 31^{\circ} 25^{\prime} \mathrm{S}\right)$, where the climate is temperate with dry winters, according to Köppen classification. The average annual temperature is $18^{\circ} \mathrm{C}$, with average minimum temperature of $6.6^{\circ} \mathrm{C}$ in July and maximum of $31.6^{\circ} \mathrm{C}$ in January. The average annual rainfall is $750 \mathrm{~mm}$. The main crop surveyed was Brassica oleracea var. capitata L., where weekly collections of larvae and pupae of DBM were made during spring 2006 and 2007.

Since the identification of discrete pest generations is difficult because overlapping, sampling was based on estimates of total density of larvae and pupae of the pest and of parasitoids in a given period, using graphic methods by Southwood \& Jepson (1962). When high pest population level was observed (more than three individuals per plant), random sampling of apparently healthy immature started. The insects collected were separated into four groups (Mills 1992) in laboratory, base on size: small larvae (Ls) for instars L1 and L2; medium larvae (Lm) for L3; large larvae (L1) for L4; and pre-pupae and pupae (P). The specimens were placed individually in Petri dishes of $5.5 \mathrm{~cm}$ diameter, reared at 22 $\pm 2{ }^{\circ} \mathrm{C}$ and $60 \pm 5 \% \mathrm{RH}$. Larvae were fed daily with pieces of fresh cabbage leaves. The dishes were checked daily for emergence of either moths or parasitoids and for insect mortality. Adult parasitoids were placed individually in ethanol at $70^{\circ}$ until identification. Total parasitism rate for each species and year were determined. Larvae lost by handling were not included in the analysis.

The parasitoid species identified in our work were all Hymenoptera attacking larvae and pupae of DBM: Diadegma insulare (Cresson, 1865) (Ichmeumonidae), Cotesia plutellae (Kurdjumov, 1912) (Braconidae) and Oomyzus sokolowskii (Kurdjumov, 1912) (Eulophidae).

Diadegma sp. is a primary parasitoid of first larval instar, but death occurs in the pupal stage after the formation of the cocoon. Guilloux et al. (2003) observed a significant increase in parasitism ( $\mathrm{p} \mathrm{d} \bullet 0.01)$ from L2 to L3 by other species of this genus, D. leontiniae (Bret). The Eulophidae $O$. sokolowskii is a worldwide gregarious parasitoid that attacks immature forms, but prefers third and fourth instar larvae (Talekar \& Hu 1996) and pre-pupae and pupae (Nakamura $\&$ Noda 2001). On the other hand, C. plutellae can attack all instars; however, parasitism decreases with age of the host.

In 2006, sampling started on October $18^{\text {th }}$, when it was recorded the maximum pest density and it was followed weekly until November $22^{\text {nd }}$. In 2007 , DBM sampling was performed from August $21^{\text {st }}$ to November $28^{\text {th }}$.

Among the 1077 individuals of DBM collected in 2006 (Table I), 28.8\% reached the adult stage, while $11.1 \%$ were killed by entomopathogenic fungi, and $60.3 \%$ by parasitoids. The highest rate of adult emergence were when Ll individuals were parasitized $(43.1 \%)$ even when this group had the highest entomopatogenic fungus mortality (28.4\%) compared to $\operatorname{Lm}(17.6 \%)$ and $\operatorname{Ls}(17.9 \%)$.

In 2007, from 684 immature individuals collected, 50.4\% reached the adult stage $21.9 \%$ died by entomopathogenic fungi; and $27.7 \%$ by parasitoids. Adult's emergence trend was similar to that observed in the year before, with L1 parasitized larvae resulting in the highest rate, $27.2 \%$, which was lower than in 2006. No specimens of Chalcididae were collected in this period (Table I).

Table I. Natural factors of mortality on each developmental stage of Plutella xylostella (DBM), in cabbage crop in Santa Fe, Argentina, in 2006 and 2007.

\begin{tabular}{|c|c|c|c|c|c|c|c|}
\hline \multirow{2}{*}{ Groups } & \multirow{2}{*}{$\begin{array}{l}\text { DBM adults } \\
\text { emerged }\end{array}$} & \multicolumn{5}{|c|}{ Number of adults emerged } & \multirow{2}{*}{ Total } \\
\hline & & Cotesia plutellae & Oomyzus sokolowskii & Diadegma insulare & Entomopathogenic fungi & Chalcididae & \\
\hline \multicolumn{8}{|l|}{2006} \\
\hline Ls* & 50 & 11 & 9 & 13 & 33 & 0 & 116 \\
\hline $\mathrm{Lm}^{*}$ & 68 & 39 & 37 & 38 & 39 & 0 & 221 \\
\hline $\mathrm{Ll}^{*}$ & 90 & 28 & 66 & 36 & 48 & 0 & 268 \\
\hline $\mathrm{P}^{*}$ & 102 & 2 & 288 & 69 & 0 & 11 & 472 \\
\hline Total & 310 & 80 & 400 & 156 & 120 & 11 & 1077 \\
\hline \multicolumn{8}{|l|}{2007} \\
\hline $\mathrm{Ls}^{*}$ & 58 & 28 & 0 & 3 & 43 & 0 & 132 \\
\hline $\mathrm{Lm}^{*}$ & 69 & 55 & 4 & 3 & 62 & 0 & 193 \\
\hline $\mathrm{Ll}^{*}$ & 94 & 48 & 5 & 10 & 44 & 0 & 201 \\
\hline $\mathrm{P}^{*}$ & 124 & 0 & 25 & 8 & 1 & 0 & 158 \\
\hline Total & 345 & 131 & 34 & 24 & 150 & 0 & 684 \\
\hline
\end{tabular}

* Ls $=\mathrm{L} 1+\mathrm{L} 2 ; \mathrm{Lm}=\mathrm{L} 3 ; \mathrm{Ll}=\mathrm{L} 4$ and prepupae, $\mathrm{P}=$ pupae. 
In September 2007, heavy rains were recorded (Table II), which favored an increase in entomopathogenic fungus attack. Therefore, parasitoids effects on DBM, longevity and reproductive performance on infected hosts were significantly reduced (Schuld et al. 1999).

Table II. Rainfall during sampling periods of parasitism on Plutella xylostella in cabbage crop in Santa Fe, Argentina, in 2006 and 2007.

\begin{tabular}{clc}
\hline Year & Month & Rainfall $(\mathrm{mm})$ \\
\hline 2006 & August & 7.1 \\
& September & 4.5 \\
& October & 77.2 \\
& November & 101.8 \\
\hline 2007 & August & 22.6 \\
& September & 99.8 \\
& October & 124.2 \\
& November & 13.2 \\
\hline
\end{tabular}

In 2006, O. sokolowskii caused $37.1 \%$ of total larval mortality, followed by parasitism by $D$. insulare $(14.5 \%)$. Mortality rate increased from Ls to Ll.

Nevertheless, in Ls, the mortality of both $D$. insulare and C. plutellae (11.2 and $9.5 \%$ mortality rate, respectively) was higher than that caused by $O$. sokolowskii. In Lm, the three species of parasitoids had the same impact (17\%). In Ll and P, O. sokolowskii caused the highest mortality $(48.5 \%$ and $61 \%$, respectively).

In 2007, the highest DBM mortality was caused by $C$. plutellae (19.1\%) in all stages, followed by $O$. sokolowskii $(4.9 \%)$ and $D$. insulare $(3.5 \%)$ and the mortality rate also increased from Ls to Ll. O. sokolowskii caused the highest mortality in $\mathrm{P}$ individuals (16\%), although it was very low in $\mathrm{Lm}$ and $\mathrm{Ll}$ ( $2 \%$ for each). The highest mortality rate by $D$. insulare was for the $\mathrm{Ll}$ group (5\%).

No clear explanations can justify the prevalence of one parasitoid species over the other. In the field, competition may occur when several parasitoids coexist under suitable environmental conditions (Wang et al. 1999). This competition could be related with host initial density, parasitoid searching efficiency or aggressiveness (Ayalew \& Ogol 2006).

In Santa Fe horticultural region, biological control with this complex of parasitoid species help to reduce DBM population and it should be taken into account for integrated pest management programs (Furlong et al. 2004). However, longterm studies would provide to a better understanding of the evolution of pests, parasitoids competition and entomopathogenic fungus impacts.

\section{ACKNOWLEDGMENTS}

Financial support for this study was provided by the Universidad Nacional del Litoral (Argentina).

\section{REFERENCES}

Ayalew G. \& C. K. P. O. Ogol. 2006. Occurrence of the diamondback moth (Plutella xylostella L.) and its parasitoids in Ethiopia: influence of geographical region and agronomic traits. Journal of Applied Entomology 130: 343-348.

Furlong, M. J.; S. Zu-Hua; L. Yin-Quan; G. Shi-Jian; L. Yao-Bin; L. ShuSheng \& M. P. Zalucki. 2004. Experimental analysis of the influence of pest management practice on the efficacy of an endemic arthropod natural enemy complex of the diamondback moth. Journal of Economic Entomology 97: 1814-1827.

Garcia Campos, W.; J. H. Schoereder \& O. F. Desouza. 2006. Seasonality in neotropical populations of Plutella xylostella (Lepidoptera): resource availability and migration. Population Ecology 48: 151-158.

Guilloux, T.; M. Monnerat; M. Castelo-Branco; A. Kirk \& D. Bordat. 2003. Population dynamics of Plutella xylostella (Lep., Yponomeutidae) and its parasitoids in the region of Brasilia. Journal of Applied Entomology 127: 288-292.

Jankowska, B. \& K. Wiech. 2006. The composition and role of parasitoids in reducing population densities of diamondback moth Plutella xylostella $\mathrm{L}$. on different cabbage vegetables. Journal of Plant Protection Research 46: 275-284.

Martínez-Castillo, M.; J. L. Leyva; J. Cibrián-Tovar \& R. Bujanos Muñiz. 2002. Parasitoid diversity and impact on populations of the diamondback moth Plutella xylostella (L.) on Brassica crops in central Mexico. BioControl 47: 23-31.

Mills, N. J. 1992. Parasitoids guilds: defining the structure of the parasitoid complexes of tortricoid hosts (Lepidoptera:Tortricoidea). Environmental Entomology 21: 230-239.

Mussury, R. M.; W. D. Fernández \& E. S. Quintão Scalon. 2002. População de Diabrotica speciosa (Germar, 1824) e Plutella xylostella Linnaeus, 1758, associada a Brassica napus L. em função de dois métodos de captura. Ciência e Agrotecnologia 26: 993-998.

Nakamura, A. \& T. Noda. 2001. Host-age effects on oviposition behavior and development of Oomyzus sokolowskii (Hymenoptera: Eulophidae), a larval-pupal parasitoid of Plutella xylostella (Lepidoptera: Yponomeutidae). Applied Entomology and Zoology 36: 367-372.

Sarfraz, M. \& B. A. Keddie. 2005. Conserving the efficacy of insecticides against Plutella xylostella (L.) (Lep., Plutellidae). Journal of Applied Entomology 129: 149-157.

Schuld, M., G. Madel \& R. Schmuck. 1999. Impact of Vairimorpha sp. (Microsporidia: Burnellidae) on Trichogramma chilonis (Hymenoptera: Trichogrammatidae), a hymenopteran parasitoid of the cabbage moth, Plutella xylostella (Lepidoptera: Yponomeutidae). Journal of Invertebrate Pathology 74: 120-126.

Southwood, T. R. \& W. F. Jepson. 1962. Studies on the populations of Oscinella frit L. (Diptera: Chloropidae) in the oat crop. In: N. S. Talekar \& T. D. Griggs (Eds.). Diamondback Moth Magement. Proceedings of the Second International Workshop. Tainan, Taiwan 27: 245-253.

Talekar, N. S. \& W. J. Hu. 1996. Characteristics of parasitism of Plutella xylostella (Lep., Plutellidae) by Oomyzus sokolowskii (Hym., Eulophidae). Entomophaga 41: 45-52.

Ulmer, B.; C. Gillot; D. Woods \& M. Erlandson. 2002. Diamondback moth, Plutella xylostella (L.), feeding and oviposition preferences on glossy and waxy Brassica rapa (L.) lines. Crop Protection 21: 327-331.

Wang X.G.; S. Liu; S. Guo \& W. Lin. 1999. Effect of host stages and temperature on population parameters of Oomyzus sokolowskii, a larvalpupal parasitoid of Plutella xylostella. BioControl 44: 391-402.

Yun Cheng, E. 1985. The resistance, cross control of diamondback resistance and chemical moth in Taiwan. Diamondblack Moth Managemet. In: N.S. Talekar \& T.D. Griggs (eds.) The management of diamondback moth and other crucifer pests. Proceedings of the First International Workshop. Tainan, Taiwan 32: 329-345.

Received 2231/2011; accepted 7/8/2011

Editor: Sonia Maria Noemberg Lázzari 